\title{
III. Hadis Lisansüstü Öğrenci Sempozyumu - 19 Kasım 2021
}

\section{Nilüfer Kalkan Yorulmaz ${ }^{*}$}

Türkiye'deki İlahiyat veya İslami İlimler Fakülteleri arasında ilk defa 22-23 Kasım 2019; ikinci defa 19 Kasım 2020 tarihinde İstanbul Üniversitesi İlahiyat Fakültesi Hadis Anabilim Dalı tarafindan düzenlenen sempozyumlarda Türkiye'nin farklı üniversitelerinde öğrenimlerini sürdüren lisansüstü öğrenciler tebliğlerini takdim etmiş ve bu sunumlar farklı üniversitelerden hadis hocaları tarafından müzakere edilmiştir. Müzakerecilerin eleştiri ve görüşleri çerçevesinde tashih edilen ilk sempozyumun metinleri yayımlanmış, ikinci sempozyuma ait metinler ise yayıma hazırlanmaktadır. Yukarıda belirtilen her iki sempozyumun kapanış oturumunda dile getirilen temenni ve görüşler çerçevesinde ise bu serinin devam ettirilmesi gerektiği neticesine ulaşılmıştır. Bu minvalde İstanbul Üniversitesi İlahiyat Fakültesi Hadis Anabilim Dalı tarafından düzenlenen III. Hadis Lisansüstü Öğrenci Sempozyumu 19 Kasım 2021 tarihinde dokuz tebliğci ve müzakereci ile çevrimiçi olarak gerçekleştirilmiştir. Sempozyum, hadis alanında yüksek lisans ve doktora öğrencilerinin çalışmalarını diğer araştırmacılarla paylaşmasını, alanında uzman hocalarla fikir alışverişinde bulunarak olgunlaştırmasını ve hadis alanındaki araştırmacıları bir araya getirerek onların birbirleriyle etkileşimde bulunmasını hedeflemiştir.

Üçüncüsü düzenlenen bu sempozyumun açı1ış oturumunda İstanbul Üniversitesi İlahiyat Fakültesi Dekanı Prof. Dr. Ramazan Muslu ve İstanbul Üniversitesi İlahiyat Fakültesi Hadis Anabilim Dalı Başkanı Prof. Dr. Mustafa Ertürk konuşmalarını yapmıştır. Muslu, fakültenin bu tür akademik faaliyetlerin her zaman destekçisi olduğunu ve öğrenciler için yeni ufuklar açtığını, akademik çalışmaları nitelik açısından güçlendireceğini ve yayın hususunun önemini vurgularken; Ertürk ise sempozyumun lisansüstü alanda çalışmalarını sürdüren öğrenciler için bir firsat olarak görülmesi gerektiğine ve yapılan müzakerelerin öğrencilerin çalışmalarını olgunlaştırmada oldukça önemli olduğuna atıf yapmıştır.

Prof. Dr. Zekeriya Güler'in başkanlık yaptığg birinci oturumda Erciyes Üniversitesinde doktora öğrencisi olan Abdullah Özkul, sahâbenin hadis rivayet sayılarına etki eden

\footnotetext{
* Sorumlu Yazar: Nilüfer Kalkan Yorulmaz (Dr. Öğr. Üyesi), İstanbul Üniversitesi, illahiyat Fakültesi, Temel İslam Bilimleri Bölümü, İstanbul, Türkiye. E-posta: nilufer.yorulmaz@istanbul.edu.tr ORCID: 0000-0002-6191-8072 
yaşam süresi, meslek, coğrafya gibi durumları incelediği Sahâbîlerin Hadis Rivayet Sayılarını Etkileyen Faktörlerin Analizi isimli tebliğini sunmuş ve bu tebliğ Prof. Dr. Mustafa Karataş tarafından müzakere edilmiştir. Özkul tebliğinde hadis rivayet sayıları ile yukarıda zikredilen yaşam süresi, meslek, coğrafya gibi faktörler arasında ilişkiler kurulabildiğini ve bu ilişkilerin hadislerin sıhhatini güçlendirdiğini iddia etmiştir. Araştırmanın müzakeresini yapan Karataş ise özellikle sahâbîlerin hadis rivayet sayılarını belirlerken dikkat edilmesi gereken hususlar üzerinde durmuş̧tur. Nitekim sahâbîlerin hadis rivayet sayılarının bizlere bazı eserler aracıllı̆ıyla nakledildiği ancak kaynaklarda zikredilen sayıların üzerine düşünülmesi ve dikkatli davranılması gerektiğini belirtmiştir. Oturumun ikinci tebliği ise Vâkidî'nin titiz bir hadisçi olarak değerlendirildiği Hicrî İkinci Asırda Özgün Bir Hadisçilik Örneği: Vâkıdî’nin (ö. 207/823) Hadis Rivayet Metodu başlıklı tebliğiyle Gaziantep Üniversitesinde doktora öğrencisi olan Muhammed Talha Kılıç tarafindan takdim edilmiştir. Kılıç, Megazî̀ den hareketle Vâkidî’nin hadisçiliğini ve hadis rivayetindeki metotlarını ortaya koymaya çalışmış ve sonuçta ise Vâkidî'nin her ne kadar tarihçi olarak nitelenen bir alim olsa da hadisçiliğinin göz ardı edilemeyeceğini ve hadisçi metoduna uygun davrandığını söylemiştir. Doç. Dr. Fuat İstemi ise bu tebliğe yaptığını müzakeresinde tarihçi ve hadisçi metotlarının farkl11ıklarına vurgu yapmış ve sunumda Vakidî’nin titiz bir hadisçi olarak değerlendirilmesiyle ilgili eleştirilerini sıralamıştır.

İkinci oturuma Prof. Dr. Mehmet Özşenel başkanlık ederken bu oturumun ilk tebliği İmam Şeybânî’nin Ebû Hanîfe'ye ihtilaf etmesine yol açan etkenlerden biri olarak hadisin rolünün değerlendirildiği Hadise Yaklaşımları Açısından Şeybânî'nin Ebû Hanîfe 'ye Muhalefetinin Değerlendirilmesi ismiyle Marmara Üniversitesinde doktora öğrencisi olan Ramazan Doğanay tarafından sunulmuş ve bu tebliğin müzakeresini Prof. Dr. Mürteza Bedir yapmıştır. Doğanay tebliğinde Şeybânî'nin hadis birikimine vurgu yapmış ve bu birikimin de hadisi kıyâs ve istihsân gibi delillere öncelemesine sebebiyet verdiğini belirtmiştir. Bu husus da tebliğde hocasıyla arasındaki muhalefetin sebebi olarak gösterilmiştir. Tebliğin müzakeresini yapan Bedir ise Şeybanî’nin merfû hadisi Medinelileri tenkit ederken öne çıkardığını ancak Ebû Hanîfe'ye muhalefetinde gerçekten hadisi öncelikli bir delil görmesinin ana sebep olmadığını belirtmiştir. Bu sebeple çalışmanın hadis bağlamından ziyade daha geniş bir bağlamda ele alınması gerektiğini söylemiştir. Samsun On Dokuz Mayıs Üniversitesinde doktora eğitimini sürdüren Nurdan Genç'in takdim ettiği ve Doç. Dr. Musa Erkaya tarafından müzakeresi yapılan ikinci tebliğ ise hicri üçüncü asırda ahkâm kavramının üzerine bina edilmekte ve İbn Mâce'nin Sünen'i Özelinde Sünen Türü Eserlerde Yer Alan Ahkâm Dışı Bölümlerin Değerlendirilmesi başı̆̆ı̆ı taşımaktadır. Genç, çalışmasında sünen 
eserlerinin yalnızca ahkâma dair konuları ihtiva etmediğini belirtmektedir. Yazar, konuyla ilgili olarak kendi ifadeleriyle "Sünen başlığı genel bir isimlendirme olarak mı karşımıza çıkmaktadır? Farklı bir "sünen" tanımına ihtiyaç olduğu söylenebilir mi? Ahkâm dışı bölümlerin yer almasındaki temel etken nedir? Bu etkenler genel geçer midir yoksa müelliflerine has yönleri olabilir mi? Ahkâm dışı bölümlerin özellikleri ve mahiyetleri nelerdir?" gibi bazı sorular yöneltmekte ve çalışmasında bu soruların cevabını aramaktadır. Tebliğin müzakeresini yapan Erkaya ise konu başlı̆̆ının oldukça geniş olduğunu ve sünen ile ahkam kavramlarının birbirine karıştırılmaması gerektiğini ve ahkamın ahlaki konuları da kapsayan tanımlarının göz ardı edilemeyeceğini vurgulamıştır.

Prof. Dr. Hüseyin Hansu'nun başkanlık ettiği üçüncü oturumda yine iki sunum gerçekleştirilmiştir. Oturumun ilk tebliğcisi İstanbul Üniversitesi doktora öğrencisi olan Sait Erkam Boz, özellikle mihne sonrası dönemde hadis râvilerinin cerhinde cehmîliğin bir sebep olarak dile getirildiğini anlattığı Mihne Olaylarının CerhTa'dîlin Objektifliğine Etkisi: Cehmîlikle Tenkit Edilen Râviler Bağlamında Bir Inceleme başlı̆̆ıyla bir sunum yapmış ve bu tebliğ Prof. Dr. Abdullah Karahan tarafından müzakere edilmiştir. Boz tebliğinde mezhebine göre râvilerin tenkid edilme hususunun cerh ta dîlin tarafsızlığına etki edecek bir noktada olmadığını ve bu tenkitlerin sistemsel bir probleme yol açmadığını belirtmiştir. Karahan ise cerh ve ta dîlin ictihâdi bir mesele olduğu belirtmiş ve dolayısıyla tebliğde ulaşılan tarafsızlık sonucunun cerh ve ta dîlin doğasına aykırı olduğunu belirtmiştir. $\mathrm{Bu}$ oturuma Marmara Üniversitesinde doktora öğrencisi olan Emine Avcı'nın fedâilü'lKur'ân rivayetlerinin halku'l-Kur'ân düşüncesinin destekçisi olarak nakledilmesi hususunu ele aldığ1 Halku'l-Kur'ân Düşüncesinin Fedâilü'l-Kur 'ân Rivayetleri Üzerindeki Etkisi isimli tebliği ile devam edilmiştir. Çalışmanın müzakerecisi ise Prof. Dr. Serdar Demirel olmuştur. Avc1, ashâbu'l-hadîs ve re'yi tanıtmış ve bu ekollerin Kur'ân'ı nasıl anladıklarına değinmiştir. Bu minvalde fedâilu'lKur'ân rivâyetlerinin ashâbu'r-re'y olarak tanımlanan Mu'tezile ekolü tarafından halku'l-Kur'ân anlayışını temellendirmede delil olarak kullanıldığı iddia etmiştir. Demirel ise Kur'ân'ının yaratılmışlığını destekleyen rivayetleri, böyle düşünmeyen ashâbu'l-hadîsin neden eserlerinde naklettiği sorusu üzerinde durmuştur. Ayrıca Demirel, tebliğ sahibi tarafından bu konuda yapılan çıkarımın daha derinlemesine araştırılması gerektiğini vurgulamıştır.

Sempozyumun Prof. Dr. Abdullah Karahan tarafından başkanlığı yapılan kapanı̧̧ oturumundan önceki son oturumunda ise üç tebliğ sunulmuştur. Bu oturumda Yozgat Bozok Üniversitesi yüksek lisans öğrencisi İsmail Evcin'in Kütüb-i Sitte'den alınan hadislerin Ahmed Yesevî'nin Divân-ı Hikmet isimli eserindeki ahiret tasavvuruna etkilerini belirlemeye çalıştı̆̆ Ahmed Yesevî'nin Dîvân-ı Hikmet'inde Ahiret 
Tasavvurunun Oluşmasında Hadislerin Etkisi adlı sunumu Prof. Dr. Ahmet Yıldırım; Marmara Üniversitesi doktora öğrencisi Seher Öztoprak'nn sûfî/zâhidliğin bir râvinin tenkidi için sebep olarak görülüp görülmediğini incelediği Muhaddislerin Erken Dönem Zâhidleri Tenkit Nedenleri Üzerine Bir Inceleme başlıklı çalışması Prof. Dr. Abdullah Aydınlı; İnönü Üniversitesi yüksek lisans öğrencisi Feyza Sağdıç'ın Hind b. Ebû Hâle'yi tanımayı, kendisinden gelen rivayetleri zikretmeyi, rivayetinin zayıf kabul edilme sebeplerini tespit etmeyi amaçladığı Hind b. Ebû Hâle ve Hz. Peygamber 'in Şemâiline Dair Rivayeti isimli tebliği ise Prof. Dr. Yusuf Ziya Keskin tarafından müzakere edilmiştir.

Evcin tebliğinde Ahmet Yesevi Uluslararası Türk-Kazak Üniversitesi tarafından bastırılan Dîvân-ı Hikmet nüshasından hareketle ahiret ile ilgili kavramları belirlemiş, bu kavramları hadislerde araştırmış ve böylece etkilenilmesi muhtemel hadisler ile Ahmet Yesevî'nin hikmetlerini eşleştirmiştir. Tebliğin müzakeresini yapan Yıldırım, konunun genişliğine, başlık ve içerik arasındaki uyumsuz noktalarına ve yazarın kendinden önceki birikimden yararlanması konusundaki eksikliklerine temas etmiştir. Oturumun ikinci tebliğini sunan Öztoprak, Kuşeyrî’ den hareketle ele aldığı çalışmasında hadis münekkitleri açısından bir râvinin sûfí/zâhid olmasının cerh sebebi olarak görülmediği sonucuna ulaşmıştır. Bu tebliğin müzakeresini yapan Aydınlı ise zâhid ve sûfinin aynı anlamda değerlendirilemeyeceğini ve farklı olarak ele alınması gerektiğini söylemiştir. Bu bağlamda çalışmada kullanılan ıstılah ve kavramlara dikkat edilmesi gerektiğini vurgulamıştır. Ayrıca çalışmada sûfilerin hadis rivayetinde neden çok titiz olmadıkları hususuna da değinilmesi gerektiğini belirtmiştir. Oturumun ve sempozyumun son mübelliği Sağdıç'ın tebliğinde sahabî olarak nitelenen Hind b. Ebû Hâle'nin Buhârî'nin Duafâu'l-Kebîr'inde zikredilmesi üzerinde durulmuştur. Yazar, bu hususun sahabenin adaleti meselesi ile yakından ilgili olduğunu söylemiştir. Ancak Sağdıç sunumunda bu meseleye sadece işaret edileceğini fakat bu konunun sebepleri üzerinde durulmayacağını belirtmiştir. Tebliğin müzakeresini yapan Keskin ise öncelikle çalışmalarda başlık ve içerik uyumuna vurgu yapmış ve giriş niteliğindeki bilgilerin çok fazla uzun tutulmamasının önemini belirtmiştir. Ayrıca Keskin, Buhârî’nin Hind b. Ebû Hâle'yi değil rivayetini zayıf gördüğünün özellikle belirtilmesinin önemine işaret etmiştir. Bununla birlikte bazı terimlerin anlamının müellife göre değişebileceğini ve 1stılahların bu minvalde değerlendirilmesi gerektiğini ifade etmiştir. Son olarak Keskin, meselenin açıklanması hususunun başka çalışmalara bırakılması yerine bu çalışmada zikredilmesinin daha doğru olacağını söylemiştir.

Sempozyumun son oturumu olan kapanış oturumu ise Prof. Dr. Abdullah Aydınlı, Prof. Dr. Zekeriya Güler, Prof. Dr. Abdullah Karahan, Prof. Dr. Mustafa Ertürk, Prof. Dr. Hüseyin Hansu, Dr. Öğr. Üyesi Seyit Ali Güşen ve Dr. Öğr. 
Üyesi Nilüfer Kalkan Yorulmaz'ın katılımıyla gerçekleştirilmiştir. Sunulan tebliğler ve yapılan müzakerelerin genel bir değerlendirmesinin yapıldı̆̆ kapanış oturumunda öğrencilerin özellikle süreye riayet ve akademik üslup konusunda başarılı bulundukları belirtilmiştir. Bunun yanında çalışmalarını oluştururken kendilerinden önceki birikimden yararlanma konusundaki eksiklikleri dile getirilmiştir. Ayrıca araştırmacıların 1stılahların kişiye veya döneme göre değişen farklı kullanımları hususunda daha müteyakkız olmalarının ve kapsam olarak geniş konular yerine daha derinlemesine çalışabilecekleri hususi konular seçmelerinin gerekliliği vurgulanmıştır. Tüm bunlarla beraber genç araştırmacıların çalışmasının olgunlaşmasını sağlamak ve daha ileri düzeye taşımak adına yapılan bu sempozyumun aynı veya farklı formatlarda sürekli hale getirilmesinin önemi zikredilmiş ve ilgili yerlere yapılan teşekkür konuşmalarıyla sempozyum sona ermiştir. 
